\title{
IMPLEMENTING THE RESPONSIBILITY TO PROTECT IN LIBYA
}

\author{
Ciprian Buzatu ${ }^{1}$ \\ "Carol I" National Defence University
}

\begin{abstract}
The last decade of the $X X^{\text {th }}$ century was marked by three major humanitarian crises, in Rwanda, Bosnia and Herzegovina and Kosovo. The international community adopted different approaches to these situations, but they all had in common a sense of failure. Today, we see that such catastrophic situations continue to exist in places like Yemen or Syria, where civlian populations face atrocity crimes. These are just two examples of ongoing humanitarian crises and we have to keep in mind to there is an imminent risk for the escalation of disastrous conflicts in countries such as Ethiopia or Myanmar. By 2005, the United Nations adopted a comprehensive tool for avoiding and approaching situations where the lives of civilians are in peril, namely, the responsibility to protect. The analysis of its use in Libya, having NATO as a main actor, will reveal the reasons this tool is not as effective as the world hoped in the moment of its creation, and, hopefully, will contribute to an enhanced understanding of the responsibility to protect.
\end{abstract}

Keywords: humanitarian; atrocitiy; risk; responsibility to protect.

\section{INTRODUCTION}

On March 23, 1999, the North-Atlantic Treaty Organisation (NATO) launched a bombing campaign in Yugoslavia, also known as Operation Allied Force, without having an authorization from the United Nations Security Council (UNSC). The allies focused their attacks on the territorial infrastructure of Serbia, including bridges and electric and fuel networks, which contrbuited in a decisive manner to the end of the Kosovo conflict, on July 10, 1999. This conflict shocked the entire world with its ethnic cleansing and other atrocities. (Tatum 2010, 133)

NATO's intervention on humanitarian grounds in Kosovo was undertaken without the existence of an UNSC resolution, which should have provided the required international mandate for approaching the situation. The lack of official approval at UN level for intervention in Kosovo was mainly based on Russia and China's unfavorable stances regarding such an approach. In contrast to the divergent opinions at UNSC level on Kosovo's conflict, Rwanda's catastrophic situation from 1994 was approached at the same level by deciding to stand aside. This was a dilemma underlined by the former UN Secretary-General Kofi Annan, while presenting his annual report in September 1999 to the UN General Assembly. (Annan 1999)

The solution for tackling the tensely-debated dilemma, mainly created by NATO's intervention in Kosovo, for approaching situations with populations being threatened by genocide, ethnic cleansing, crimes against humanity and war crimes, was called the responsibility to protect (R2P). It was created at the Canadian Government's initiative, which contributed to the activity of the International Comission for Intervention and State Sovereignty (ICISS). The 12 members of ICISS released, in December 2001, The Responsibility to protect: Report of the International Comission on Intervention and State Sovereignty, a document which promoted a new perspective for approaching the challenges related to humanitarian intervention, such as sovereignty, and detailed in a comprehensive manner the R2P concept. (Evans, et al. 2001, 1-9)

In essence, the concept promoted by ICISS says that the state has the main responsibility for protecting its population, and, when it can not do that, does not want or it is the perpetrator of aggression itself, the responsibility to protect belongs to the international community. The concept

${ }^{1}$ Corresponding author: buzatu_ciprian@yahoo.com 
contains three dimensions - the responsibility to prevent, the responsibility to react and the responsibility to rebuild - having names that suggests a multitude of tools and measures that can be used in situations such as those mentioned before. (Evans, et al. 2001, 17)

After considerable efforts for creating, defining and promoting the responsibility to protect, the final version of the concept was adopted in the 2005 World Summit Outcome, paragraphs 138-140. (60/1. World Summit Outcome 2005, 30)

Furthermore, an important perspective for understanding and analysing R2P was included in a report of a former United Nations (UN) Secretary-General, Ban Ki Moon. His report indicated that R2P has three pillars. The first (The protection responsibilities of the States), and most important, represents the responsibility of the state in protecting its population, having in mind the responsibility generated by sovereignty and other relevant legal obligations. (Moon 2009, 10-14) The second pillar (International assistance and capacity-building) represents the commitement of the international community in offering a multidimensional assistance that can help certain states in overcoming challenges related to protecting their populations. (Moon 2009, 15-22) The third pillar (Timely and decisive response) is the action taken by UN member states, based on the caractherisitcs of the situation, for helping those populations that are not protected by their states. (Moon 2009, 22-28)

Considering that it involves to posibility of using force, the third pillar is the most controversial part of R2P. There are two conditions that require to be met in order to implement this pillar. These are part of Paragraph 139, 2005 World Summit Outcome: "should peaceful means be inadequate and national authorities are manifestly failing to protect their populations from genocide, war crimes, ethnic cleansing and crimes against humanity." In such situations, UN's member states should be prepared to act in accordance with the nature of the situation observed at the ground level, while considering the possibility of cooperating with relevant regional organizations. (60/1. World Summit Outcome 2005, 30) The third pillar was further clarified by Ban Ki Moon in his 2012 report, Responsibility to protect: timely and decisive action, where it was underlined that its purpose consists in assisting or persuading national authorities to meet their responsibilities to their populations. (Moon 2012, 4) The specific measures available to use "when a state does not respond to diplomatic and other peaceful means" are established by Articles 41 and 42, Chapter VII, of the UN Charter. Examples of actions specific to Article 41 are sanctions such as freezing of financial assets belonging to the government or certain individuals, imposition of travel bans, controlling the availability of weapons, limiting the diplomatic contact with the target state. Actions specific to Article 41 involve the use of force and some examples are deployment of UN multinational forces for creating security zones or no-fly zones, or for establishing a military presence on land or sea for protection or deterrence purposes. The specific types of measures applied are determined by the UNSC, considering the operational details. (Moon 2012, 9)

The three responsibilities or dimensions (prevent, react, rebuild), defined by ICISS and mentioned earlier, were not adopted as part of the UN language. In this article, they will be used as tools for analysis, considering that they contribute to the correlation between R2P and the relevant events mentioned in the next section of the article. Furthermore, considering that they include common measures, it is also important to mention the dimensions' role in understanding the relation between the UN's peace operations (conflict prevention, peacemaking, peace enforcement, peacekeeping, peace building) and the responsibility to protect. (United Nations Peacekeeping Operations. Principles and Guidelines 2008, 17-19)

Having noted these main details as part of a baisis for understanding the responsibility to protect, the next sections of the article will aim at providing a short description of the Libyan conflict from 2011, underlining events relevant for analysing R2P.

\section{THE LIBYAN CONFLICT'S ESCALATION}

According to certain perspectives, the Arab Spring have begun in Tunisia, in 2011, after a fruit seller set himself on fire, angry with the measures adopted by the local authorities. This incident contributed to the escalation of tensions between the Tunisian population and the authorities, situation transposed subsequently in other regional states, but, the foundations of this dynamic can be 
identified in Lebanon. In march 2005, after the assassination of the country's prime minister, there were peaceful protests that demanded the retreat of Syrian security forces from Lebanon. After a month of efforts, the protestors demand was fulfilled. The name attributed to this movement is the Cedar Revolution and it represented a very strong democratic signal for the entire arab world. (Haas and Lesch 2013, 70)

After the dynamic of the Arab Spring reached Tunisia and Egypt, the escalation of the Libyan population's complaints, related to socio-political issues, happened in Benghazi. The main reason for escalation was the arrest of a human rights lawyer, named Fathi Tarbil, involved in representing the families of the victims from the Abu Salim prison incident, that happened in 1996, when many prisoners were allegedly killed by the security forces of the regime. (Vandewalle 2012, 203-204) Hundreds of protestors gathered in front of a police station, in the day of february 15, 2011, and the security forces responded by using live ammuniton against the protestors, causing 10 deaths. Two days later, hundreds of thousands of peaceful protestors occupied the streets of multiple cities from the Cyrenaica region, namely Benghazi, Ajbadiyah, Darnah and Zintan, situation approached by Gaddafi's regime by using force, marking the moment of tensions escalation. (Haas and Lesch 2013, 64) The protestors dissatisfaction was generated by multiple issues: "corruption, repression, frustration, fear, authoritarianism, cronyism, extreme centralization, indifference to widespread youth unemployement, phony elections, poor governance, arrogance, patronizing attitudes, lack of due process, little accountability or transparency, partisan judicial procedures, bribes and nepotism." (Lobban and Dalton 2014, 128) The historical division between the Libyan regions of Cyrenaica (east) and Tripolitania (west) was once again a highly relevant subject for the internal Libyan environment. Part of this contrast was that, on one hand, the anti-Gaddafi movement rapidly developed in the eastern region, obtaining acces to weapons from unsecure garrisons of the Libyan forces, while, on the other hand, the regime managed to maintain the public order in the western region, where the motivation against Gaddafi was not that high. In Tripolitania, fear, propaganda and actions of the police and foreign mercenaries were efficient measures until a certain point. (Lobban and Dalton 2014, 132)

Gaddafi's popularity in Cyrenaica was always lower compared to the other Libyan regions, Tripolitania and Fezzan. His coercive measures used against the local tribes were once efficient, but in the current situation, there was an active and intense support between the local tribes and the general population, which included both random individuals with a certain level of education and public servants or members of the army that opposed Gaddafi's regime. The regional dynamic, mentioned before, also contributed to this situation. Communication tools such as social media played an important role in the awreness related to local events and rapidly atracted new protestors. An example was a video with leaders of Cyrenaican tribes that declared their support for the new National Transition Council, during a highly solemn ceremony. (Haas and Lesch 2013, 71-72)

As the situation deteriorated, the National Transition Council, self-proclaimed as uniqe representant of the Libyan people, gradually obtained acknowledgment, in 2011, at international level form members of the European Union, the Arab League, and, probably most important, form the United States of America. (Vandewalle 2012, 204) On February 21, two aircrafts of the Libyan air force were bombing the city of Benghazi, already surrounded by the regime's ground troops. The next day, Gaddafi blamed the "rats and cockroaches" that opposed him in Benghazi, using words that reminded of the Rwandan genocide. (Lobban and Dalton 2014, 132)

\section{UN'S DECISIONS AND NATO'S APPROACH TO THE LIBYAN CONFLICT}

On February 26, 2011, the United Nations Security Council (UNSC) adopted the Resolution 1970, which underlined that the situation in Libya was marked by a "gross and systematic violation of human rights, including the repression of peaceful demonstrators, expressing deep concern at the deaths of civilians, and rejecting unequivocally the incitement to hostility and violence against civilians made from the hightest level of the Libyan government." "Recalling the Libyan authorities' responsibility to protect its population" and acting under the Chapter VII of the United Nations Charter, the resolution imposed an initial set of measures against Gaddafi's regime, involving an embargo on 
arms and materiels or equipment for military use, travel restrictions and asset freeze for certain individuals that violated the human rights and the international law, through actions against the civilan population. (Resolution 1970 2011)

Following the Resolution 1970, on March 8, 2011, NATO deployed Airborne Warning and Control Systems aircrafts for monitoring the situation in Libya. This measure was further strenghtened through ships deployed in the Mediteranean Sea. (NATO and Libya (Archived) 2015) The political and diplomatic initiatives of the United States of America, France and Great Britain were aiming for obtaining the UNSC's authorization for executing adittional coercive measures for solving the Libyan conflict. (Heihr and Murray 2013, 65-67)

Considering the lack of a positive evolution in Libya, UNSC adopted the Resolution 1973, on March 17, 2011. The document reiterated "the responsibility of the Libyan authorities to protect the Libyan population and reaffirming that parties to armed conflicts bear the primary responsibility to take all feasible steps to ensure the protection of civilians" and taked into consideration "the widespread and systematic attacks currently taking place in the Libyan Arab Jamahiriya against the civilian population may amount to crimes against humanity". Under the Chapter VII of the United Nations Charter, the Resolution authorized states to take all neccessary measures (Article 42, UN Charter) for protecting the civil population and the zones they inhabited, being under the threat of the regime's forces attacks. One important point is that exercising the control of a part of the Libyan territory through occupation forces was not authorized. A no-fly zone was created in the Libyan airspace, denying all the flights in this space. Also, the measures imposed by Resolution 1970 were further consolidated. (Resolution 1973 2011)

From the point of view of the responsibility to protect, Resolution 1973 authorized the implementation of the third pillar (Timely and decisive response) or the responsibility to react dimension. UNSC authorized in the undertaking Article 42 (UN Charter) type of actions in Libya, through a peace enforcement operation. On March 19, 2011, Operation Odyssey Dawn was launched in Libya, a multinational operation led by Washingtion, which involved coercive measures that contributed to implementing the provisions established by Resolution 1973. (Gertler 2011, 4) These measures can be summarized in the following paragraph: "The no-fly operation was enabled by a strike against Libyan air-defense assets and other targets using 110 Tomahawk and Tactical Tomahawk cruise missiles and strikes by three B-2 Spirit bombers delivering 45 Joint Direct Attack Munitions (JDAMs) against Libyan air bases. 16 Tomahawks were also fired from British ships in the area, and British Tornado GR4 aircraft flying from the Royal Air Force base at Marham, England, reportedly employed Storm Shadow cruise missiles." (Gertler 2011, 7)

At the end of March 2011, the operational command was transfered to NATO, replacing Operation Odyssey Dawn with Operation Unified Protector. According to NATO, the operations' objectives where enforcing the neccesary arms embargo in the Mediterranean Sea, enforcing a no-fly zone in Libya and conducting air and naval strikes against military entities that attacked or posed a threat to the Libyan population. (NATO and Libya (Archived) 2015) Besides NATO member states, Qatar and the United Arab Emirates joined the operation by making available a combined number of 20 aircrafts that contributed to imposing the no-fly zone. (Gertler 2011, 20)

Meanwhile, at ground level, the city of Misrata was a point of intense military activities, being a strategic point in the regime's resource resupplying network from the east of the country. Gaddafi's forces made considerable efforts for denying the success of international humanitarian initiatives, and, besides mining actions in the city's port, they have bombarded, with Grad type missiles, strategic locations for the overall safety of the population, blocking the access to supplies, food, water, electricity or communications. The siege of Misrata was lifted mid-May, but, until the, thousands of civilians have been killed and the city's infrastructure was destroyed. (Lobban and Dalton 2014, 133)

The international coalition's actions also generated civilian casualities. One such incident happened after bombing a location near the city of Surman, owned by one of Gaddafi's allies, after which 15 persons were killed. Furthermore, the regime charged NATO with killing a similar number of civilians, during the attacks executed in Brega. (Lobban and Dalton 2014, 134-135) (Brega Airstrike 2011) 
On August 21, 2011, the opposition forces where launching Operation Mermaid Dawn (referring to the "Mermaid" nickname atributted to Tripoli). This was the sieige of the Libyan capital, organised by rebels that gathered in Zawiya, Gharyan and Misrata. The siege took place both at ground and sea level, with boats coming form Misrata. This initiative was also supported by the forces that participated to Operation Unified Protector. After losing the capital on August 22, 2011, the regime was only holding control of Sirt, Bani Walid and Sabha. (Lobban and Dalton 2014, 138-139)

Resolution 2009, adopted on September 16, 2011, underlined the UNSC's support for the National Transition Council, in the context of reconstructing Libya, and established the United Nations Support Mission in Libya (UNSMIL), for an initial period of 3 months, having a mandate that should have contributed to Libya's stabilization and reconstruction through actions such as promoting an inclusive political dialogue, with the aim of achieving national reconciliation, assisting the Libyan authorities in enhancing the capabilities of local institutions, promoting the rule of law and protecting human rights, taking necessary steps for the country's economic recovery. (Resolution 2009 2011)

After capturing Tripoli, there were signs of transition to normality in Libya. The National Transition Council was preparing the plans for reconstrucion and international actors were considering to resume diplomatic and economic relations with Libya. For example, in Septembre 2011, the United States embassy in Tripoli was reopened and the American ambassador was announcing the interest of about 150 american companies for business oportunities in the conuntry. On October 18, 2011, the American State Secretary Hillary Clinton made a visit to Tripoli for celebrating the results obtained. (Lobban and Dalton 2014, 140-142) The reconstruction could not be done while Gaddafi was still free. The rebel's efforts for finding his location were successful two months after capturing Tripoli. On October 20, 2011, Muammar Gaddafi was captured and killed in the city of Sirt. (Lobban and Dalton 2014, 141-142)

On October 27, 2011, UNSC announced the termination of the multinational operation and the lifting of certain sanctions imposed against Libya, through Resolution 2016: „Welcomes the positive developments in Libya which will improve the prospects for a democratic, peaceful and prosperous future there." (Resolution 2016 2011)

Behind a state of celebration generated by the liberation of the Libyan people from the regime, certains factors, with long term effects, were developing. There were political issues at the level of the National Transition Council, which suggested a lack of unity between the new leaders, transposed at local level through a lack of various militas loialty. Also, once the regime lost the control of arms deposits, the access to weapons was available for rebels who had no military training and who lacked a well organised chain of command. (Lobban and Dalton 2014, 137-140) On October 31, 2011, UNSC adopted Resolution 2017, related to the mentioned issue: "Expressing concern at the proliferation of all arms and related materiel of all types, in particular man-portable surface-to-air missiles, from Libya, in the region and its potential impact on regional and international peace and security." (Resolution 2017 2011)

\section{THE ASSESSEMENT OF IMPLEMENTING THE R2P IN LIBYA}

This part of the article will be built using the theoretical basis established in the Introduction section and the contextual aspects provided in the second and third sections. The objective of this section is to assess the results of Operation Unified Protector and to contribute to their correlation with the current state of the responsibility to protect.

Starting with the responsibility to prevent dimension, if it is considered that the escalation of a conflict towards war represents the proof of prevention's failure, then the assessment of this part of the Libyan conflict can be rapidly done. It is still important to determine whether the best possible decisions and measures were adopted at this level of the Libyan conflict. The responsibility to prevent was determined by the measures authorized in Resolution 1970, detailed in the third section of this article. It is also relevant for this level of the analysis, to mention that the situation in Libya deteriorated rapidly, process indicated by events on the ground and the sharp loss of credibility, reliablility or trustworthiness of Gaddafi's regime. Considering that the first pillar of the responsibility to 
protect was not effective anymore, the local population being under an imminent risk posed by Gaddafi's forces, it was necessary to implement measures specific to the third pillar of R2P.

In other words, the operational situation in Libya imposed the authorization of measures specific for the responsibility to react. This action happened through the adoption of Resolution 1973. It is unfortunate for the overall evolution of the responsibility to protect that there is a concern related to the real objective of Operation Unified Protector. This aspect is probably related to the heritage left behind by humanitarian intervention, which was often synonymized with regime change, a problem that should have been solved by the responsibility to protect. More specifically, the actions that produced civilan casualities, exemplified in the third section of this article, raised questions that asked wether NATO's actions further deteriorated the local situation. Another aspect of concern is the presence on the ground of Qatari forces, with hundreds of troops supporting Libyan rebels through training, communications and strategy. (Black 2011) It is difficult to assess the entire set of actions the Qatari forces conducted at ground level. From one point of view, this situation can be equated to territorial occupation, not authorized by the UN, but from another perspective, it can be considered that the Qatari representatives did not deviate form the mandate and offered support for protecting the local population. There is a clear assessement that can be done considering all these details, indicating an overall level of transparency that was not ideal for the responsibility to react and for the third pillar of R2P.

NATO's involvement in Libya officialy ended on October 31, 2011, with the Secretary General Jens Stoltenberg stating that the Alliance conducted one of its most successful operations, that fully complied with the mandate given by the UNSC. (NATO Secretary General statement on end of Libya mission 2011) However, the Peace Support Operations Doctrine (AJP-3.4.1) states that "The actual success of an operation will therefore be measured against the overall result and not just on the achievement of the military objectives." (Peace Support Operations AJP-3.4.1 2001, Chapter 2, 2) and "All too often, once the conflict has been brought to an end, the attention of the international community moves on, the peace building phase of the mission plan is under-resourced and the operation stalls." (Peace Support Operations AJP-3.4.1 2001, Chapter 2, 7)

After the conflict in Libya apparently ended in 2011, there was no solid initiative for a peacebuilding process. The responsibility to rebuild dimension had almost no content for Libya, excepting UNSMIL, an operation which was unable to approach the local challenges. It proved to be only a matter of months before the cyclic nature of conflicts was demonstrated in Libya.

\section{CONCLUSIONS}

The Libyan conflict from 2011 is unique from the R2P's point of view. It was an important step for this concept's evolution and a test that it did not manage to pass, mainly because a certain lack of transparency during the responsibility to react and, more importantly, because the responsibility to rebuild was missing. Having in mind the diverse visions and interests of the Security Council's permanent member states, R2P is a concept that can not be fully embraced by the international community, thus there are situations that can not benefit from a R2P approach. The concept can still provide it's spirit, acting as a political commitement reminded in situations of genocide, ethnic cleansing, crimes against humanity and war crimes, where the local civilians can only hope that this will be enough to save their lives.

For NATO, conducting an operation that lacked transparency and that was not followed by the required step for stabilizing Libya and bringing the country to a healthy path, proves the necessity for improvement, at least at the level conducting of peace operations. Considering NATO's aim of adopting a more global approach (Stoltenberg 2021, 11), there is an important possibility of encountering challenges that share aspects with the Libyan conflict. Such a scenario would be a test both for NATO, which will have to prove its level of multidimensional robustness, and for the UN, which will probably have to choose between one of the two notorious models of approaching situations that involve atrocities: the Rwandan model of avoidance or the Kosovo model of acting without UNSC authorization. 


\section{REFERENCES}

"60/1. World Summit Outcome." 2005. October 24. Accessed March 03, 2021. https://undocs.org/A/RES/60/1

Annan, Kofi. 1999. "Press Release SG/SM/7136 GA/9596". September 20. Accessed March 03, 2021. https://www.un.org/press/en/1999/19990920.sgsm7136.html.

Black, lan. 2011. "Qatar admits sending hundreds of troops to support Libya rebels". October 26. Accessed March 06, 2021. https://www.theguardian.com/world/2011/oct/26/qatar-troops-libyarebels-support.

"Brega Airstrike". 2011. May 13. Accessed March 05, 2021. https://www.nato.int/ cps/en/natohq/news_74247.htm?selectedLocale=en

Evans, Gareth, Mohammed Sahnoun, Gisèle Côté-Harper, Lee Hamilton, Michael Ignatieff, Vladimir Lukin, Klaus Naumann, et al. 2001. "The Responsibility to Protect. Report of the International Commission on Intervention and State Sovereignty". December. Accessed March 26, 2021. https://idl-bnc-idrc.dspacedirect.org/bitstream/handle/10625/18432/IDL18432.pdf?sequence=6\&isAllowed $=y$

Gertler, Jeremiah. 2011. "Operation Odyssey Dawn (Libya): Background and Issues for Congress". March 03. Accessed March 04, 2021. https://fas.org/sgp/crs/natsec/R41725.pdf.

Haas, Mark L., and David W. Lesch. 2013. The Arab Spring. Change and Resistance in the Middle East. Westview Press.

Heihr, Aidan, and Robert Murray. 2013. Libya, the Responsibility to Protect and the Future of Humanitarian Intervention. Palgrave Macmillan.

Lobban, Richard A., and Cristopher H. Dalton. 2014. Libya. History and Revolution. Santa Barbara: Praeger.

Moon, Ban Ki. 2009. "Implementing the Responsibility to Protect". January 12. Accessed March 05, 2021. https://www.un.org/ruleoflaw/files/SG_reportA_63_677_en.pdf.; 2012. "Responsibility to protect: timely and decisive action." July 15. Accessed March 05, 2021. https://undocs.org/A/66/874

"NATO and Libya (Archived)". 2015. November 09. Accessed March 04, 2021. https://www.nato.int/cps/en/natohq/topics_71652.htm

"NATO Secretary General statement on end of Libya mission." 2011. October 28. Accessed March 07, 2011. https://www.nato.int/cps/en/natolive/news_80052.htm

"Peace Support Operations AJP-3.4.1." 2001. July. Accessed March 07, 2021. https://info.publicintelligence.net/NATO-PeaceSupport.pdf

"Resolution 1970". 2011. February 26. Accessed March 04, 2021. http://unscr.com/en/ resolutions/doc/1970.

"Resolution 1973". 2011. March 17. Accessed March 04, 2021. http://unscr.com/en/ resolutions/doc/1973

"Resolution 2009". 2011. September 16. Accessed March 05, 2021. http://unscr.com/en/ resolutions/doc/2009

"Resolution 2016". 2011. October 27. Accessed March 05, 2021. http://unscr.com/en/ resolutions/doc/2016.

"Resolution 2017". 2011. October 31. Accessed March 05, 2021. http://unscr.com/en/ resolutions/doc/2017. 
Stoltenberg, Jens. 2021. "The Secretary General's Annual Report 2020". March 16. Accessed March 26, 2021. https://www.nato.int/nato_static_fl2014/assets/pdf/2021/3/pdf/sgar20-en.pdf

Tatum, Dale C. 2010. Genocide at the Dawn of the 21st Century: Rwanda, Bosnia, Kosovo and Darfur. New York: Palgrave Macmillan.

"United Nations Peacekeeping Operations. Principles and Guidelines". 2008. January 18. Accessed March 05, 2021. https://peacekeeping.un.org/sites/default/files/capstone_eng_0.pdf

Vandewalle, Dirk. 2012. A History of Modern Libya. New York: Cambridge University Press. 